Журнал «Герспективитаінноваціїнауки»

(Серія«Гедагогіка»), Серія«ГТихологія», Серія «Медицина»

№5(5) 2021

УДК 781.42:[378.018.8:373.011.3-051:78]

https://doi.org/10.52058/2786-4952 -2021-5(5)-606-613

Умрихіна Оксана Станіславівна кандидат педагогічних наук, доцент, доцент кафедри інструментального виконавства, Уманський державний педагогічний університет імені Павла Тичини, вул. Гоголя, 22,кв. 2, м. Умань, 20300, тел.: (093) 511-39-19, e-mail: roza2223@ meta, https://orcid.org/0000-0002$1735-1152$

\title{
ХУДОЖНЬО-ПЕДАГОГІЧНИЙ АНАЛІЗ ПОЛІФОНІЧНИХ ТВОРІВ ЯК НЕОБХІДНА СКЛАДОВА ФАХОВИХ УМІНЬ МАЙБУТНЬОГО ВЧИТЕЛЯ МУЗИЧНОГО МИСТЕЦТВА
}

Анотація. Статтю присвячено художньо-педагогічному аналізу поліфонічних творів як необхідної складової фахових умінь майбутнього вчителя музичного мистецтва, визначаються особливості сприйняття поліфонії як важливої музиної форми.Досліджуються погляди науковців щодо визначення сутності та змісту поняття «художньо-педагогічний аналіз», його впливу на розвиток професійних навичок вчителя музичного мистецтва. Виокремлено теоретичні знання, практичні навички й уміння, якими слід послуговуватися у процесі художньо-педагогічного аналізу. Описуються основні форми роботи, які формують у майбутніх фахівців вміння художньопедагогічного аналізу поліфонічних творів.

Описуються основні форми роботи, які формують у майбутніх фахівців вміння художньо-педагогічного аналізу поліфонічних творів. Виділяються найбільш типові недоліки при написанні студентами анотацій та здійсненні усного аналізу музичних творів під час аудиторних занять і проходження різних видів педагогічної практики. Наголошується на тому, що формування у студента вищезазначених вмінь має здійснюватися систематично протягом усього періоду навчання у закладі вищої освіти. Також розроблено зміст і визначено структурні компоненти художньо-педагогічного аналізу поліфонічного твору, а також обсяг знань і вмінь, які пов'язані з художньопедагогічним аналізом як необхідної складової фахових умінь майбутнього вчителя музичного мистецтва.

Ключові слова: поліфонія, художньо-педагогічний аналіз, заклад вищої освіти, музично-теоретична підготовка, професійно-педагогічна спрямованість навчання, методичний аналіз навчального матеріалу.

Umrykhina Oksana Stanislavivna Candidate of Pedagogical Sciences, Associate Professor, Associate Professor of the Department of Instrumental Performance, Uman State Pedagogical University named after Pavel Tychyna, Gogol St., 22, apt. 2, Uman, 20300, tel.: (093) 511-39-19, e-mail: roza2223@meta, https://orcid.org/0000-0002-1735-1152 


\section{ARTISTIC AND PEDAGOGICAL ANALYSIS OF POLYPHONIC WORKS AS A NECESSARY COMPONENT OF THE PROFESSIONAL SKILLS OF THE FUTURE TEACHER OF MUSICAL ARTS}

Abstract. The article is devoted to the artistic and pedagogical analysis of the analysis of polyphonic works as a necessary component of professional skills of the future teacher of musical art. The views of scientists on the definition of the essence and content of the concept of "artistic and pedagogical analysis", its impact on the development of professional skills of music teachers are studied. Theoretical knowledge, practical skills and abilities that should be used in the process of artistic and pedagogical analysis are highlighted. The main forms of work that form the skills of artistic and pedagogical analysis of polyphonic works in future specialists are described.

The main forms of work that form the skills of artistic and pedagogical analysis of polyphonic works in future specialists are described. The most typical shortcomings in the writing of annotations by students and the implementation of oral analysis of musical works during classes and the passage of various types of pedagogical practice. It is emphasized that the formation of the student's above skills should be carried out systematically throughout the period of study in a higher education institution. The content and structural components of the artistic and pedagogical analysis of a polyphonic work, as well as the scope of knowledge and skills related to the artistic and pedagogical analysis as a necessary component of the future professional skills of a professional are also summarized and identified.

Keywords: art-pedagogical analysis, institution of higher education, musictheoretical training, professional-pedagogical orientation of education, methodical analysis of educational material.

Постановка проблеми. Художньо-педагогічний аналіз поліфонічного твору $\epsilon$ невід'ємною частиною професійних умінь майбутнього вчителя музичного мистецтва. Він існує i як самостійна складова заняття, i як допоміжний методичний засіб в організації різних форм музичної діяльності. Виконання поліфонічного твору, як своєрідної різнобарвної партитури значно розвиває образно- художнє мислення інструменталіста i покращує його професійний рівень як виконавця. Власне осмислення та вміле використання поліфонічних творів учителем у навчальній роботі зі студентом допомагає осягти образний світ музики, сприймати іiі художні образи, оволодівати специфікою музичної мови, що й дає можливість робити художньопедагогіний аналіз поліфонічного твору на заняттях 3 інструментального виконавства. 3 метою пошуку шляхів удосконалення організаційної, змістової й професійної підготовки майбутнього вчителя музичного мистецтва науковці досліджують різноманітні прийоми, що сприяють формуванню вміння здійснювати організацію художньо-педагогічного аналізу поліфонічного твору, яке 3 набуттям професійної майстерності надає змогу майбутньому вчителю 
Журнал«Герспективитаінноваціїнауки

(Серія «Гедагогіка», Серія «Гиихологія», Серія«Медицина»

№5(5) 2021

музиного мистецтва здійснювати активне навчання, яке передбачає використання системи методів і прийомів, необхідних для оволодіння знаннями, уміннями, навичками.

Аналіз останніх досліджень і публікацій. Аналіз наукових джерел дає змогу розглянути проблему виконавської підготовки, пов’язаної з художньопедагогічним аналізом поліфонічних творів у різних методиках вивчення поліфонії як музичного твору. Художньо-педагогічний аналіз поліфонічних творів у контексті нашого дослідження розглядається як необхідна складова фахових умінь майбутнього вчителя музичного мистецтва, спрямована на виокремлення i одночасно об'єднання основних елементів та законів написання поліфонії як музичного твору. На заняттях з інструментального виконавства згідно програми студент систематично працює над виконанням поліфонічних творів, що позначається на його загальній виконавській діяльності. Аналізуючи останні дослідження і публікації слід зауважити,що проблема інструментально-виконавської підготовки музичних педагогів стала предметом багатьох наукових досліджень. Вітчизняними науковцями розроблені концептуальні положення щодо фахової підготовки студентів у інструментальному класі (Л. Арчажникова, , М. Давидов, О. Олексюк, Г. Падалка, О. Рудницька, , О. Щолокова та ін.); упроваджені в практику методики формування у майбутніх учителів музиного мистецтва інструментальних навичок (О. Бурська, , Л. Гусейнова, Е.Економова, В. Лапченко, I. Мостова, , Г. Ніколаї, А. Омельченко, , В. Федоришин, О. Щербініна та ін.), досліджено процес розвитку теоретичних та практиних умінь студентів в інструментальному класі (І. Гринчук, , О. Ляшенко, Н. Сегеда та ін.). На основі концепцій А. Лосєва, В. Андрєєвої, В. Куклєва, А. Овчиннікової про знаково-символічні засоби, у працях I. Манакової, Н. Салміної, Т. Тютюнникової та ін. розкрито деякі аспекти художньопедагогічного аналізу. Незважаючи на значну кількість праць, присвячених проблемі художнього, зокрема художньо-педагогічного аналізу поліфонічних творів у фаховій підготовці майбутнього вчителя музичного мистецтва є досі невирішеними.Також питанням художньо-педагогічного, глибокого i повноцінного виконавства творів музичного мистецтва присвячували свої науково-методичні праці відомі психологи і педагоги-музиканти (Б.Асаф’єв, В.Бєлобородова, Н.Ветлугіна, ， Є.Назайкінський, В.Остроменський, О.Ростовський, та ін.). Але процес формування інструментально-виконавської компетентності майбутнього вчителя музичного мистецтва та сутність цього феномену ще недостатньо досліджені, що й визначило актуальність цієї статті.

Мета статті. Удосконалення професійної музично-теоретичної підготовки майбутнього вчителя музичного мистецтва засобами художньо-педагогічного аналізу поліфонічних творів; оволодіння практичними навичками аналізу поліфонічних творів в єдності форми та змісту, яке може бути використано в подальших заняттях та самостійній творчій роботі майбутніх вчителів музичного мистецтва ; виховання художнього смаку, почуття стилю, 
поліфонічної грамотності, формування об'єктивних критеріїв оцінювання явищ музичної культури, розвиток творчих здібностей студентів.

Виклад основного матеріалу. Процес осмислення художньопедагогічного образу поліфонічного твору вимагає з боку педагога насамперед визначити що ж таке поліфонія. Поліфо́нія (від грец. poly - багато i phone звук) - вид багатоголосся, у якому окремі мелодії, або групи мелодій мають самостійне значення i самостійний інтонаційно-ритмічний розвиток, зберігаючи рівноправність голосів та незбігання в різних голосах каденцій, цезур, кульмінацій, акцентів та ін.[7].

На заняттях 3 інструментального виконавства розбираючи зміст i структуру поліфонічного твору, вчитель повинен завжди співвідносити рівень підготовки студента та кінцевим результатом виконання поліфонічного твору в цілому, зважувати свої педагогічні наміри 3 пізнавально - творчими можливостями учнів. Тому аналіз поліфонічного твору, $є$ аналізом художньопедагогічним. Художнім - тому що аналізується твір мистецтва і цей аналіз випливає 3 його закономірностей; педагогічний - тому, що проводиться 3 урахуванням музичного розвитку і завдань музичного виховання. Художньопедагогічний аналіз без зайвого спрощення співвідносить емоційно-образний зміст твору з інтересами і можливостями слухачів і забезпечує естетичне осягнення ними даного твору, тобто сприяє реалізації виховної і пізнавальної функції музичного мистецтва в їх єдності.

Як зауважив у своїй статті Маринчук Т.Т про теоретичні основи художньо-педагогічного аналізу поліфоніного твору як необхідної складової у фаховій підготовці вчителя музичного мистецтва приходимо до формулювання самого поняття. Пі художньо-педагогічним аналізом розуміємо особливий вид педагогічної діяльності, спрямований на виявлення характеру художніх образів та усвідомлення змісту й ідеї художнього твору; здійснений з урахуванням вікових особливостей, рівня художньо-естетичного розвитку певної категорії школярів і виховних завдань; донесений до школярів у доступній та цікавій формі. Теоретичні підвалини художньо-педагогічного аналізу складають теоретичні знання: 1) в галузі культурології, мистецтвознавства та суміжних дисциплін; 2) в галузі певного виду мистецтва, серед яких чільне місце посідають знання про засоби виразності у мистецтві; 3) в галузі вікової психології. Також для здійснення художньо-педагогічного аналізу педагог повинен володіти практичними уміннями і навичками оформлення цих знань у чітку послідовну розповідь для школярів відповідної вікової групи; використання міжпредметних зв'язків. Результатом художньо-педагогічного аналізу стає налагодження художньої комунікації школярів 3 твором мистецтва. Для цього слід створити й певні педагогічні мови, зокрема забезпечити активне творче сприйняття художнього твору («подіяпереживання»); зафіксувати силу й глибину емоційного переживанняпотрясіння; виявити особистісне відношення до твору мистецтва; створити умови для вербалізації свого сприйняття-відношення. 3 метою конкретизації 
Журнал«Герспективита інновації наукиљ

(Серія«Гедагогіка»), Серія«ГТихологія», Серія «Медицина»

№5(5) 2021

положень художньо-педагогічного аналізу у подальшому слід створити алгоритми для його здійснення стосовно конкретних видів та жанрів мистецтва [10].

Робота над поліфонічною літературою є однією із найбільших складнихі важливих областей навчання майбутніх вчителів музичного мистецтва. Художньо-педагогічний аналіз поліфонічного твору не тільки активізує одну із важливих сторін сприйняття музики, але і розвиває інтелектуальне музичне мислення майбутнього фахівця. Великого значення у цьому процесі набуває вміла й цілеспрямована музично-освітня робота, професійна підготовка, педагогічний талант, майстерність, багатство інтелекту і душевної чуйності вчителя, який має орієнтувати учнів на осмислення інтонаційно - пластичних витоків музики, самостійну інтерпретацію художнього світу твору. Тут (на індивідуальних заняттях 3 інструментального виконавства) педагог повинен застосовувати різні вербальні, виконавські та педагогічні й методичні прийоми, необхідні форми, методи роботи, навчаючи студента самостійно розкривати художній образ поліфонічного твору у виконавській та акторській інтерпретаціях, а також реалізувати їх у різноманітних формах виконавської практики. Для майбутнього вчителя музичного мистецтва, основна мета практичної діяльності якого - забезпечення контакту своїх вихованців 3 різножанровою музикою, безумовно необхідним $\epsilon$ всебічне уявлення про музичне мистецтво, художньо-педагогічний аналіз конкретного музичного твору. Великого значення в даній проблемі набуває формування музичного кругозору і організація художньо-оцінювальної діяльності студентів, озброєння ïх знаннями i навичками, необхідними для самостійного художньопедагогічного аналізу поліфонічних творів, а також підвищення рівня художнього виховання засобами музичного мистецтва.

Фахові уміння вчителя музичного мистецтва будуть ефективними під час вирішення наступних завдань: знання 3 художньо-педагогічного аналізу поліфонічного твору; вміння розкривати поліфонічний зміст твору у єдності 3 його формою; здатність встановлювати навчально-виховну ціль у використанні поліфонічного твору на уроці, визначати труднощі у сприйманні або виконанні даного матеріалу. Найголовніше, про що повинен пам'ятати виконавець при виконанні поліфонії -це досягнення безперервності руху та разом із тим проведення теми поліфонічного твору в різних голосах шляхом різного їх виконання у тембрально-динамічному звучанні, виразності інтонування кожної лінії, пластичності голосоведення, прослуховування логіки руху i співвідношення голосів.

Недостатність інтелектуального та емоціонального потенціалу в практиці музично-педагогіної підготовки студентів, вказує на особливе значення i актуальність використання різних форм роботи над поліфонією. Вирішення проблем якісної підготовки майбутнього вчителя музиного мистецтва вимагає удосконалення інструментальної підготовки 3 орієнтацією на проникнення у художній образ. Пропонуємо детально викласти етапи роботи 3 поліфонічним 
твором у процесі навчання:

1. Ознайомлення з твором уцілому.

2. Розбір, вивчення голосів окремо і разом.

3. Сольфеджування голосів.

4. Виконання студентом і педагогом поперемінно лівою і правою рукою.

5. Робота над штрихами та артикуляцією.

6. Робота над тембральною стороною звуку, над інтонацією.

7. Вивчення по фрагментах двома руками.

8. Робота над темпом, його єдністю [8].

Цілісний аналіз музичного твору можна провести, лише вміючи повноцінно розібратися у всіх даних нотного тексту (чому вчить елементарна теорія музики), розуміючи гармонійні і тональні явища, правильно оцінюючи фактурні особливості (чому вчить гармонія), розуміючи в більш тісному плані закономірності співвідношення декількох мелодійних ліній, а в більш широкому - формотворну роль різних явищ багатоголосся (чому вчить поліфонія). Додамо до цього, що повноцінний розбір музичного твору немислимий без опори на дані музично-історичної науки. Отже, величезну роль в даному виді аналізу відіграє порівняння, в ході якого одні твори порівнюються з іншими - схожими і відмінними. Але це можливо тільки тоді, коли накопичений відомий "багаж" музичної літератури. А його накопичення іде поступово, і кожна музична дисципліна сприяє цьому .

Висновки. На відміну від багатьох фахових дисциплін, які читаються в навчальному закладі мистецького профілю різного рівня, фортепіано виступає як обов'язковий предмет для усіх музичних спеціальностей, оскільки різнобічна спрямованість предмету передбачає його тісний зв'язок з усіма музичними виконавськими та теоретичними дисциплінами. Специфіка напрямку підготовки знаходить своє відображення у змісті, формах та методах роботи в класі фортепіано.

В результаті майбутній вчитель музичного мистецтва повинен знати: зміст навчального матеріалу, мати системні, повні, міцні знання в обсязі та в межах вимог навчальної програми, усвідомлено використовувати їх у розв’язанні актуальних проблем розвитку музично-педагогічної освіти, при аналізі поліфонічних творів композиторів різних епох, навчально-методичних матеріалів, робити правильні висновки, приймати обгрунтовані рішення; історію поліфонічної музики, особливості поліфонічних творів композиторів різних епох і шкіл, періодизацію та еволюцію поліфонічних жанрів і стилів; знання й уявлення про основні закономірності поліфонічного багатоголосся як засобу формотворення й музичної виразності; уміти: досконало володіти понятійним апаратом, мати сформовані міцні практичні навички 3 подальшого самостійного опрацювання музично-теоретичних питань, уміти самостійно аналізувати та застосовувати теоретичні знання на практиці для вирішення інноваційної діяльності, уміти оцінювати, узагальнювати опанований матеріал, 
самостійно добирати та користуватися джерелами інформації; сприяти розвитку й вдосконаленню культури художнього сприйняття майбутніх учителів музичного мистецтва засобами поліфонічної музики композиторів різних епох.

\section{Jimepamypa:}

1. Асафьев Б.В. Избранные статьи о музыкальном просвещении и образовании. 2-е изд. Л.: Музыка, 1973.144 с.

2. Баренбойм Л. А. Вопросы фортепианной педагогики и исполнительства Л.: Музыка, 1969. 289 с.

3. Выготский Л.С. Психология искусства СПб.: Азбука, 2000. 416 с.

4. Гегель Г. Энциклопедия философских наук.: В 3-х т. М.: Мысль, 1977. Т. 1. 452 с.

5. Грищенко Т.А. Робота над поліфонічним матеріалом на заняттях у класі фортепіано - методичні рекомендації для студентів рівня вищої освіти бакалавр, спеціальності 013 Початкова освіта, спеціалізації «Музика». - Слов’янськ: Вид-во Б. І. Маторіна, 2018. - 48 c.

6. Гродзенская Н.Л. Школьники слушают музику. М.: Просвещение, 1969. 77 с.

7. Евдокимова Ю. Учебник полифонии. - М. : Музыка, 2000. - 378 с

8. Зиско В.В. Робота над поліфонією у фортепіанному класі. XIV міжнародна наукова інтернет-конференція «advanced technologies of science and education» буде проведена на сайті http://int-konf.org/

9. Ляшенко О. Д. Формування фахової компетентності майбутніх учителів музичного мистецтва. Наукові записки. Вип. 139. Серія: Педагогічні науки. Кіровоград: РВВ КДПУ ім. В. Винниченка, 2015. С. 83-87.

10. Маринчук Т.Т. Художньо-педагогічний аналіз музичного твору як необхідна складова фахових умінь вчителя початкової школи.Науковий журнал «Молодий вчений» ВДПУ імені М.Коцюбинського. Випуск № 5.2(57.2), травень 2018. - С. 18-23.

11. Музыкальная энциклопедия / За ред. Ю.В. Калдыш. М.: Советская энциклопедия, 1973. T. $1.1072 \mathrm{c}$.

12. Остроменский В.Д. Восприятие музыки как педагогическая проблема. К.: Музична Україна, 1975. 200 с.

13. Ройтерштейн М.И. Музыкальный анализ - профессиональное умение школьного учителя. Музыкальное воспитание в школе. Вып. 16. М.: Музыка, 1985. 92 с.

14. Тельчарова Р.А. Музыка и культура (Личностный подход). М.: Знание, 1986. 64c.,

\section{References:}

1. Asaf'ev, B.V. (1973). Izbrannye stat'i o muzykal'nom prosveshhenii $i$ obrazovanii [Selected articles on music education]. L.: Muzyka [in Russian].

2. Barenbojm, L. A. (1969). Voprosy fortepiannoj pedagogiki i ispolnitel'stva [Questions of piano pedagogy and performance]. L.: Muzyka [in Russian].

3. Vygotskij, L.S. (2000). Psihologija iskusstva [Psychology of Art]. SPb.: Azbuka [in Russian].

4. Gegel', G. (1977). Jenciklopedija filosofskih nauk [Encyclopedia of Philosophical Sciences]. M.: Mysl' [in Russian].

5. Grishhenko, T.A. (2018). Robota nad polifonichnim materialom na zanjattjah u klasi fortepiano - metodichni rekomendaciï dlja studentiv rivnja vishhoï osviti bakalavr, special'nosti 013 Pochatkova ocvita, specializaciï «Muzika» [Work on polyphonic material in piano classes guidelines for students of higher education bachelor's degree, specialty 013 Primary Education, specialization "Music"]. - Slov'jans'k: Vid-vo B. I. Matorina [in Ukrainian]

6. Grodzenskaja, N.L. (1969). Shkol'niki slushajut muziku [Students listen to music]. M.: Prosveshhenie [in Russian]. 

Russian].

7. Evdokimova, Ju. (2000). Uchebnik polifonii [Textbook of polyphony]. - M. : Muzyka [in

8. Zisko, V.V. Robota nad polifonicju u fortepiannomu klasi. HIV mizhnarodna naukova internet-konferencija "advanced technologies of science and education" [Work on polyphony in the piano class. The 14th International Scientific Internet Conference "Advanced Technologies of Science and Education"] Retrived from http://int-konf.org/ [in Ukrainian]

9. Ljashenko, O. D. (2015). Formuvannja fahovoï kompetentnosti majbutnih uchiteliv muzichnogo mistectva [Formation of professional competence of future teachers of music]. Naukovi zapiski. Serija: Pedagogichni nauki - Proceedings. Series: Pedagogical Sciences, 139, 83-87 [in Ukrainian]

10. Marinchuk, T.T. (2018). Hudozhn'o-pedagogichnij analiz muzichnogo tvoru jak neobhidna skladova fahovih umin' vchitelja pochatkovoï shkoli [Artistic and pedagogical analysis of a musical work as a necessary component of the professional skills of a primary school teacher]. Naukovij zhurnal «Molodij vchenij»-Scientific journal "Young Scientist", 5.2(57.2), traven' 2018, 18-23 [in Ukrainian]

11. Kaldysh, Ju.V. (1973). Muzykal'naja jenciklopedija [Music Encyclopedia] [in Russian].

12. Ostromenskij, V.D. (1975). Vosprijatie muzyki kak pedagogicheskaja problema [Perception of music as a pedagogical problem]. K.: Muzichna Ukraïna ] [in Russian].

13. Rojtershtejn, M.I. (185). Muzykal'nyj analiz - professional'noe umenie shkol'nogo uchitelja. Muzykal'noe vospitanie $v$ shkole [Music analysis is a professional skill of a school teacher. Music education at school.]. M.: Muzyka [in Russian].

14. Tel'charova, R.A. (1986). Muzyka i kul'tura (Lichnostnyj podhod) [Music and culture (Personal approach)]. M.: Znanie [in Russian]. 